\title{
Development of environmentally friendly technologies with spiral movement of aggregates for landscape agriculture
}

\author{
Sergey Strekalov ${ }^{1, *}$, Lubov Strekalova ${ }^{2}$, and Mikhail Pertsev ${ }^{2}$ \\ ${ }^{1}$ Volgograd State Technical University, Volgograd, Russia \\ ${ }^{2}$ Volgograd State Agrarian University, Volgograd, Russia
}

\begin{abstract}
Enhancing process energy efficiency and increasing labor productivity in different areas including agriculture are first and foremost related to the use of robotic tools. This article presents a robotic tool based on a spiral motion system, highlighting the power supply elements of the tool, helix pitch distance and the speed of the structural elements. The paper also considers spiral system active drive options which use renewable power sources to supply power to the operating machine. The paper reviews the state of farming and considers ecological aspects of landscape farming. A spiral farming scheme has been developed geared towards small agricultural operations in different agribusiness segments, using unified wave-type equipment for robotic systems.
\end{abstract}

The current regulation of relations between man and natural environment contributes to a more sustainable development of the biosphere. In Russia, a stepwise system of greening the economy has been adopted, so as to preserve and restore the environment [1], which presupposes the necessity to take into consideration the environmental regularities of joint functioning of plants, equipment and devices influencing the plant object when designing landscape farming systems.

Multiple transformations of the land use system in the country have led to modern and largely privately-owned land structures characterized by internal isolation and rather remote location of operational structures in relation to one another. As a result, small businesses have been unable to procure costly mechanized special-purpose equipment for their production processes, which, in turn, has reduced agricultural production intensity on small land plots by increasing the share of manual labor accompanied by higher energy prices.

The unprofitability of capital investments in agricultural companies calls for the need to develop principally new technical facilities and technologies for agricultural production, harvesting and processing, using alternative energy sources.

Russian Government Resolution No. 1234-p of 23 August 2003 approved the 2020 Energy Strategy of Russia, which makes an emphasis on the use of renewable energy and underlines the importance of reducing the environmental stress induced by the fuel energy

${ }^{*}$ Corresponding author: strekalov sergey@mail.ru 
sector, providing energy to decentralized consumers and regions with long-distance and seasonal fuel supply schemes and decreasing remotely supplied fuel costs.

Measures aimed to support unconventional energy plant owners operating in agricultural territories are of particular interest to agricultural businesses. There is a recurrent interest in structures used both for electric power generation and for driving different work tools, such as pumps feeding water to water supply systems of residential and livestock houses and agricultural land irrigation.

This indicates that the area of agricultural robotic system development is likely to result in a more economical use of energy, time and materials, which is one of the preconditions for production intensification leading directly to economy and optimality [2, 3].

A number of basic operations can be established in landscape agriculture: soil preparation, sowing, crop tending and collecting or harvesting grown produce [5].

In this regard, it is necessary to solve a number of specific problems: 1) identifying weed plants and impacting precisely on its location for the purpose of its mechanical removal; 2) orienting the robotic device towards the spaces between rows; 3) creating propulsion units which are to reduce the negative impact on the soil, at the same time acting as work tools for elimination of weed plants in the spaces between rows; 4) developing work tools of the robotic work tool device allowing proper harvesting and packing; 5) transporting the harvested crop [4].

Each of these operations is performed with a work tool which has to comply with the agrotechnical requirements regarding cultivation of different crop plants and is capable to implement the task under given technical circumstances. Thus, good quality soil preparation imposes requirements with regard to operating depth uniformity, surface ridgeness and crumbly condition; when sowing, it is necessary to ensure uniform positioning and depth of seed placement and proper seedbed conditions; when harvesting, the essential requirements are crop retrieval, crop quality, etc.

Intensive farming systems lead to soil fertility deterioration (due to soil erosion and dehumification). In addition, when used in labor-intensive segments such as vegetable growing, melon growing, etc., for the purpose of replacing low-productivity manual labor using available technical devices (cultivators, weeding disks), it does not allow ensuring the required crop plant growth and development conditions in full. The use of weed-fighting chemicals results in lowering the consumer quality of the produce and higher levels of anthropogenic pollution. [6].

That is the reason why climatic cropping patterns have been replaced by adaptive landscape agriculture, which presupposes rational placement of crop plants and cultivars with account for the specific landscape conditions in accordance with their agro-ecological and agro-technological requirements. The adoption of conservation farming methods shall include the entire variety of landscape and special crop rotation organization, selecting an optimal soil preparation system within a broad spectrum ranging from plowing to no-tillage with a number of subsoil, flat-cutting, minimal and moldboard tillage methods used separately or in combination. Making a practical use of latest technical advances, particularly, precision farming, which is also referred to as site specific crop management, is one of the most essential technological factors underlying the formation of highly productive landscapes [8].

Following advances in information technologies, a high-tech agricultural production system featuring a precision farming system which includes GPS technologies is being introduced $[7,9]$.

Further improvements in land farming systems will be related to robotization of production processes. Here, we include bridge farming, which makes it possible to reduce the negative impact of propulsion systems on soil and make the nature of agriculture similar to industrial production with the highest level of process mechanization, automation and 
computerization. In the 1930-s, M.A. Provatorov proposed a bridge farming system which consisted in a long space framework moving along guide rails on carts, with ploughs, harrows and planters alternately attached to it as required by the production process. The use of that technology provided ample opportunity to reduce labor costs, improve performed process quality, introduce automated production systems and master the precision farming technology. However, until now the bridge farming system has only been applied modestly due to the use of guiderails and a rather sophisticated compensation system for lateral loads which come to exist due to the lack of symmetry of operating forces. An agricultural operating machine based on the bridge farming system is described in [11]. Instead of guide rails, the machine uses flexible wire ropes and automated movement of the work tool carriage along the framework during farming operations, as well as for work tool replacement after the tillage operation is complete. This technology can be used to mechanize plant growing in agriculture, in particular, for growing crop cultures in greenhouses, hotbeds and other enclosed structures, as well as on small seed growing and gardening plots. The machine ensures that its work tools are firmly fixed relative to plant rows during its movement in the field and enables plant care without disrupting the soil structure, as the ground wheels of the machine move along the same rut (track) on the border of the land plot.

Since the land plot size available to small agricultural business is limited and due to the versatility of operations to handle plants, saplings, bushes, etc., it is necessary to search for the most effective techniques and methods which can reduce manual labor costs, taking into account the anthropogenic environmental impact mitigation factor and the unity of natural and agricultural landscapes.

The designed spiral farming system used in small agricultural business makes it possible to master a wider range of crop rotation systems, technologies and techniques, including advanced eco-friendly technologies for growing medicinal herbs and small fruit crops [14].

It is necessary to devise an operation algorithm for the spiral farming system being developed and implementing its human interaction. The essential process controls include collecting data and uploading the databank on soil characteristics, fertility, meteorological conditions, agrotechnical parameters, etc., processing and integrating data taking into account the heterogeneity of survey plot information, and, eventually, interacting with the manager determining and planning production to ensure higher crop yields.

The land is prepared in accordance with the process flow chart taking into consideration the agroclimatic conditions and cartographic characteristics of the planned production. Land preparation includes the following operations:

- marking the location of the main elements of the cultivated land plot including area calculations for the cultivated crop;

- determining the power potential of the renewable energy source and placement of transformation devices;

- cutting a spiral for planting or simultaneous sowing;

- positioning technical facilities ensuring the processes of soil handling, irrigation, plant care, harvesting, etc.;

- planning a utility area to store produce and materials, produce processing units, etc.;

Figure 1 shows a spiral soil farming method diagram [13].

The spiral technology can be implemented in a number of ways, including rigid (rack, chain, etc.), elastic (wire rope, cable, etc.) and navigation (GPS, 'navigator' system) arrangements. The latter is possible due to advanced information technologies and access to global (satellite) positioning systems. Depending on the process requirements, concurrent operations, combined trailed machines and multipurpose unit attachments are used in the system [ ]. 
The spiral movement of the operating machine occurs with a constant pitch which is equal to the distance between the rows of the cultivated crop, whereas the technical implementation of the unit includes a rack, a carrier and a gear (Fig.1,2).

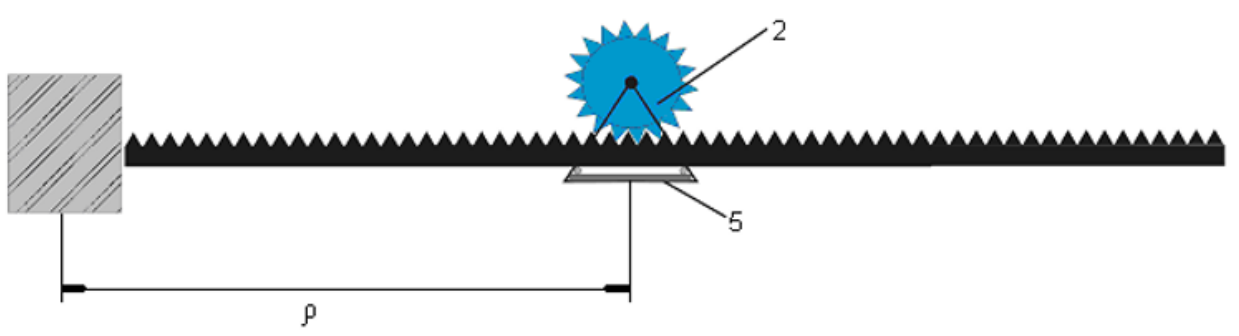

Fig. 1. Spiral farming device. Plan view

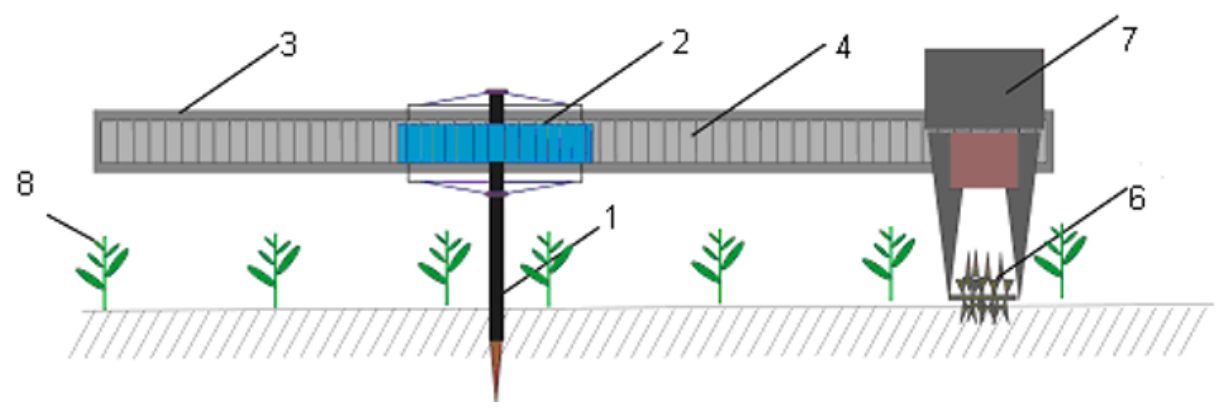

Fig. 2. Spiral farming device. Front view

The rack spiral system consists of the axle 1, which is fixed in the center of the plot. The gear 2 is attached rigidly to the axle. The gear size is determined as per $L=2 \pi R, R=L / 2 \pi$, where $L$ is the distance between rows; $R$ is the gear radius, accommodating the rack 3 , having the same pitch as the gear. The rack is fixed on the carrier 4 , which can roll over the gear because of the dolly 5 , which ensures interaction between the gear and the carrier. The work tool 6 is fixed at the carrier end and is driven by the motor 7, which is powered from solar energy converters. The motor 7 connected to the work tool 6 ensures its motion at a constant speed. Further, the carrier 4 with the mounted rack pressed by the dolly 5 to the gear 2, which is fixed to the axle 1 , rolls around spirally with a constant pitch, thus performing different process operations depending on the type of the installed work tool. When the carrier is in motion, the rack, which is installed in a manner that allows it to roll over the fixed gear, comes into mesh with the fixed gear and leads the work tool along the row by means of the carrier.

The work tool travel $\rho$ depends on the linear velocity $v_{p o}$ and the distance between rows as follows:

$$
\rho=\sqrt{\frac{L v_{p o} t}{2 \pi}}
$$

where $\rho$ is the carrier travel; $L$ is the spiral pitch (the distance between rows); $v_{n}$ is the work tool velocity $(\mathrm{m} / \mathrm{sec})$, and $t$ is time, sec.

Electrically powered machines which are known to be used for agricultural needs reveal a number of advantages over conventional machinery [12]. A geared motor with a battery is used in the spiral system to drive the active work tools, the operating machine and the 
trailed transport. Power supply is provided from a power generating unit located in the center of the cultivated land plot (Fig. 3).

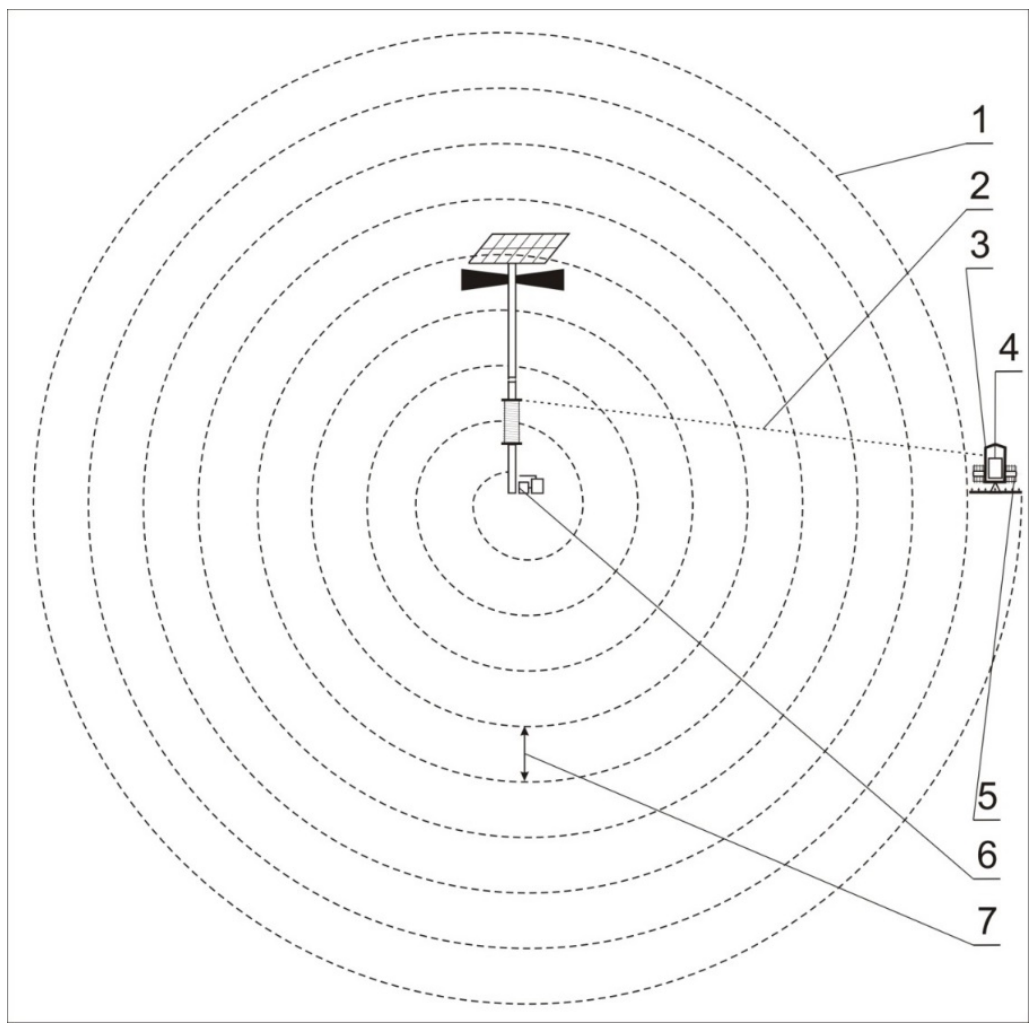

Fig. 3. Spiral landscape farming system diagram (general view): 1 - spiral; 2 - guide; 3 - operating machine; 4 - power supply: 5 - active drive, 6 - RES power generator; 7 - row spacing

The operating machine 3 is actuated by the active drive 5, powered from the power supply unit 4 , along the spiral 1 with a constant pitch, forming the row spacings 7 of the same width, due to the guide 2 , which is connected with the operating machine.

The operating machine 3 and the active work tool drive are powered from the power generator which accumulates renewable energy (solar panels, wind generator, biofuel). The power generator can be installed in the center of the spiral or in an area which is not worked by the spiral.

The power generator also performs control modes and adjusts the renewable energy with the power supply unit.

The movement of the operating machine along the spiral at a constant pitch around one fixed point, which is the spiral center, with a constant linear velocity is ensured by the process set values of the row spacing 7 and the size of the spiral itself. When passing the row spacings 7 along the spiral 1, the operating machine provides a minimum protection zone during soil tillage and plant care [13].

The developed spiral technology makes it possible to perform intensive field operations to prepare a piece of land for organizing an agricultural piece of land, to care for planting material, including propagation, combined and non-combined watering and fertilization, soil loosening after each watering operation, required hilling with mechanical elimination of weed plants, and periodic pest and disease control operations as necessary. In addition, combining traction equipment with a trailed platform for collectors ensures the most convenient collection and transportation of containers and produce. 
By applying renewable energy sources in landscape farming to power plant care devices, it will be possible to achieve higher crop production efficiency, farming community stabilization and environmental safety of land use.

\section{References}

1. A.V. Letuchiy (comp.) Agrolandshaftnoe zemledelie: kratkiy kurs lektsiy dlya studentov 4 kursa napravlenie podgotovki 21.03 .02 Zemleustroystvo $i$ kadastry [Agricultural landscape farming: a brief course of lectures for 4th year students specializing in 21.03.02 Land Management and Inventory] (FGBOU VO Saratov GAU, Saratov, 2016)

2. S.D. Strekalov, G.M. Misharev, L.P. Strekalova, Volnovaya tekhnika [Wave equipment] (Peremena, Volgograd, 2004)

3. P.R. Andronov, M.Z. Dosaev, S.D. Strekalov, G.Ya. Dynnikova, Yu.D. Selyutskiy, Izvestiya RAN. Problemy mashinostroeniya i nadezhnosti mashin. [Izv. RAN. Issues in Machine Building and Machine Reliability], 86-91 (2009)

4. S.D. Strekalov, Volnovaya tekhnika v sel'skom khozyaystve [Wave equipment in agriculture] (IPK FGOU VPO VGSHA Niva, Volgograd, 2007).

5. A.I. Kashtanova (ed.), Nauchnye osnovy sovremennykh sistem zemledeliya [Science basis for modern crop farming systems] (Agropromizdat, Moscow, 1992)

6. Revolyutsionnye tekhnologii zemledeliya. Kratnoe uvelichenie effektivnosti [Breakthrough crop farming technologies. Manifold increase in efficiency] (portalenergo.ru, Analitika, Ob"ekty energosberezheniya, Sel'skoe khozyaystvo, 15 July 2013)

7. A.I. Belenkov, Tsentr tochnogo zemledeliya - strategiya razvitiya innovatsionnogo obucheniya [Precision farming center - innovative training development strategy], Agronomiya i lesnoe khozyaystvo, Vestnik Nizhnevolzhskogo agrouniversitetskogo kompleksa. [Agronomy and Forestry, Bulletin of Nizhnevolzhsky Agrarian University Complex] (Volgograd, 2008)

8. V.A. Kiryushin, A.N. Vlasenko (eds.), Adaptivno-landshaftnye sistemy zemledeliya Novosibirskoy oblasti [Adaptive landscape crop farming systems in Novosibirsk Region] (SibNIIZHim SO RASHN, Novosibirsk, 2002)

9. V.I. Kiryushin, Zemled., 6, 16-21 (2004)

10. N.A. Gutselyuk, S.V. Spiridonov, Tekhnologiya i sistema mashin v lesnom i sadovoparkovom khozyaystvakh: Uchebnoe posobie dlya studentov vuzov. [Technology and machine system in forestry and park-and-garden management. Teaching manual for university students] (PROFIKS, Saint-Petersburg, 2008)

11. https:/good-tips.pro/index.php/house-and-garden/orchard-and-garden/fruit-andberries/growing-seedlings-for-the-garden-intensive-type

12. A.M. Ganelin, M.D. Grishin, F.M. Ikhteiman, N.F. Molosnov, Elektrifikatsiya priusadebnogo khozyaystva [Homestead electrification] (1987)

13. S.D. Strekalov, A.S. Ovchinnikov, A.S. Strekalova, M.M. Pertsev, L.P. Strekalova, A.F. Lobes, RF utility model patent No. 172614, Priority No. 2016146030 of 23.11.2016, Registered on 14.06.2017

14. S.D. Strekalov, A.S. Strekalova, L.P. Strekalova, Al'tern. En. i Ek., 13-14 (177-178), 66-71 (2015) 